\title{
PENGARUH INDEPENDENSI, KOMPETENSI, PENGALAMAN, DAN AKUNTABILITAS AUDITOR TERHADAP KUALITAS JASA AUDIT (STUDI EMPIRIS PADA KAP DI JAKARTA)
}

\author{
Ferry Adang \\ Fakultas Ekonomi Universitas Tarumanagara Jakarta \\ Email: ferrya@fe.untar.ac.id
}

\begin{abstract}
The purpose of this research is to examine the empirical influence of independency, competency, experience, and auditor's accountability on audit service quality. This research was conducted by distributing 159 questionnaires to public accounting firms in Jakarta. 128 questionnaires were filled and returned and all of them were used in this research. Multiple Linear Regression method was used to test the hypothesis. The result of this research shows that independency has positive and significant influence on audit quality, competency has positive and significant influence on audit quality, experience had positive and significant influence on audit quality, and auditor's accountability had positive and significant influence on audit quality.
\end{abstract}

Keywords : Audit Service Quality, Auditor's Accountability, Competency, Experience, Independency

\begin{abstract}
ABSTRAK
Tujuan dari penelitian ini adalah untuk mengetahui pengaruh empiris independensi, kompetensi, pengalaman, dan akuntabilitas auditor terhadap kualitas jasa audit. Penelitian dilakukan dengan menyebarkan 159 buah kuesioner ke KAP di wilayah Jakarta. Kuesioner yang dikembalikan dan diisi berjumlah 128 buah dan seluruhnya digunakan dalam penelitian ini. Pengujian hipotesis dalam penelitian ini menggunakan uji regresi linear berganda. Hasil penelitian menunjukkan bahwa independensi memiliki pengaruh positif dan signifikan terhadap kualitas jasa audit, kompetensi memiliki pengaruh positif dan signifikan terhadap kualitas audit, pengalaman memiliki pengaruh positif dan signifikan terhadap kualitas audit, dan akuntabilitas auditor memiliki pengaruh positif dan signifikan terhadap kualitas jasa audit.
\end{abstract}

Kata kunci: Kualitas jasa audit, akuntabilitas auditor, kompetensi, pengalaman, independensi

\section{PENDAHULUAN}

\section{Latar Belakang}

Menurut Sukrisno Agoes (2012:4) auditing adalah suatu pemeriksaan yang dilakukan secara kritis dan sistematis, oleh pihak yang independen, terhadap laporan keuangan yang telah disusun oleh manajemen, beserta catatan- catatan pembukuan dan bukti bukti pendukungnya, dengan tujuan untuk dapat memberikan pendapat mengenai kewajaran laporan keuangan tersebut.Tujuan dari auditing adalah untuk menghasilkan laporan audit yang merupakan suatu sarana auditor untuk menentukan apakah laporan keuangan telah disajikan dan dinilai dengan wajar.Auditor atau akuntan publik merupakan pihak ketiga independen yang berarti bahwa auditor memiliki tanggungjawab untuk meningkatkan nilai dan kualitas laporan keuangan.

Laporan keuangan dari suatu perusahaan memuat informasi - informasi perusahaan baik untuk pihak internal perusahaan seperti manajer maupun untuk pihak eksternal perusahaan seperti halnya para investor. Para pengguna eksternal laporan keuangan menilai bahwa laporan keuangan yang telah diaudit oleh auditor lebih dapat dipercaya karena pihak eksternal menganggap bahwa auditor tidak bias dalam melakukan pemeriksaan laporan keuangan. Kita sedang berada di era ketika perusahaan perusahaan berusaha untuk menyajikan laporan keuangan yang lebih baik dari para 
kompetitornya. Hal ini menyebabkan tekanan yang cukup besar untuk auditor maupun untuk pihak perusahaan.

Pada satu sisi auditor memiliki tugas untuk memberikan opini atas laporan keuangan secara wajar sesuai dengan standar yang berlaku, sedangkan di sisi lain perusahaan bersedia untuk membayar fee yang lebih besar untuk auditor apabila auditor dapat memberikan opini wajar tanpa pengecualian yang belum tentu sesuai dengan laporan keuangan perusahaan. Perusahaan dapat mengeluarkan biaya yang lebih besar untuk auditor yang dapat 'memperindah' laporan keuangan perusahaan tersebut. Pada saat inilah kualitas jasa audit dapat diuji. Menurut De Angelo dalam Kusharyanti (2003) kualitas audit adalah probabilitas bahwa auditor akan menemukan dan melaporkan pelanggaran pada sistem akuntansi klien.

Dalam mempertahankan suatu kualitasaudit, terdapat beberapa faktor dalam diri auditor yang dapat mempengaruhi kualitas jasa audit antara lain adalah: independensi, kompetensi, pengalaman, dan akuntabilitas auditor. Berdasarkan Standar Auditing Seksi 220.1 (SPAP:2011) independensi bagi seorang akuntan publik adalah tidak mudah dipengaruhi karena ia melaksanakan pekerjaannya untuk kepentingan umum. Auditor yang independen memberikan penilaian yang fair terhadap laporan keuangan yang mereka audit sehingga terdapat jaminan atas laporan keuangan tersebut. Dapat disimpulkan bahwa apabila semakin kuat independensi seorang auditor maka semakin baik kualitas audit yang dihasilkan auditor tersebut.

Menurut Bedrad (1986) dalam Sri Lastanti (2005:88) kompetensi adalah seseorang yang memiliki pengetahuan dan ketrampilan yang luas serta ketrampilan prosedural yang luas yang ditunjukkan dalam pengalaman audit. Semakin kompeten seorang auditor maka semakin tinggi kualitas jasa audit yang dihasilkannya.

Faktor ketiga yang mempengaruhi kualitas jasa audit adalah pengalaman. Menurut Knoers dan Haditono (1994) dalam Asih (2006:12) pengalaman merupakan suatu proses pembelajaran dan penambah perkembangan potensi bertingkah laku baik dari pendidikan formal maupun dari pendidikan non formal atau dapat pula diartikan sebagai proses yang membawa seseorang kepada pola tingkah laku yang lebih tinggi. Dapat disimpulkan bahwa semakin banyak pengalaman auditor dalam mengaudit maka kualitas auditnya pun akan lebih baik bila dibandingkan dengan auditor yang kurang banyak pengalaman.

Faktor keempat yang dapat mempengaruhi kualitas jasa audit adalah akuntabilitas auditor. Akuntabilitas dapat didefinisikan dengan suatu bentuk dorongan psikologi yang membuat seseorang untuk berusaha mempertanggungjawabkan semua tindakan dan keputusan yang diambil kepada lingkungannya. Kualitas jasa audit dapat dipengaruhi oleh rasa kebertanggungjawaban yang dimiliki oleh auditor dalam menyelesaikan pekerjaannya.

\section{KERANGKA TEORI DAN PENGEMBANGAN HIPOTESIS}

Independensi. Dalam buku Standar Profesi Akuntan Publik 2011 seksi 220 PSA No.04, dijelaskan bahwa:

"Independensi itu berarti tidak mudah dipengaruhi, karena ia melaksanakanpekerjannya untuk kepentingan umum (dibedakan dalam hal berpraktiksebagai auditorintern). Dengan demikian, ia tidak dibenarkan memihakkepada kepentingan siapapun, sebab bilamana tidak demikian halnya, bagaimana sempurnanya keahlian teknis yang ia miliki, ia akan kehilangansikap tidak memihak yang justru paling penting untuk mempertahankan kebebasan pendapatnya." 
Menurut Alvin A. Arens $(2012 ; 134)$ ada beberapa jenis yang terdapat pada independensi diantaranya independence infact(auditor tidak memiliki kepentingan ekonomis dalam perusahaan apabila dilihat dari keadaan yang sebenarnya) dan independence in appearance (kebebasan yang dituntut dari auditor bukan hanya berdasarkan fakta saja akan tetapi harus pula bebas dari kepentingan yang kelihatannya cenderung dimilikinya dalam perusahaan).Menurut Standar Pemeriksaan Keuangan Negara (2007:30-36)mengemukakan tiga macam gangguan terhadap independensi yaitu sebagai berikut: (a) gangguan pribadi, organisasi pemeriksa perlu memperhatikan gangguan pribadi yang disebabkan oleh suatu hubungan dan pandangan pribadi mungkin mengakibatkan pemeriksa membatasi lingkup pertanyaan dan pengungkapan atau melemahkan temuan dalam segala bentuknya, (b) gangguan ektern, independensi dan obyektif pelaksanaan suatu pemeriksaan dapat dipengaruhi apabila terdapat campur tangan atau pengaruh pihak ektern yang membatasi atau mengubah lingkup pemeriksaan secara tidak semestinya, campur tangan pihak ektern terhadap pemilihan dan penerapan prosedur pemeriksaan atau pemilihan sampel pemeriksaan, pembatasan waktu yang tidak wajar untuk penyelesaian saat pemeriksaan, campur tangan pihak ektern mengenai penugasan,penunjukan dan promosi pemeriksa serta pembatasan terhadap sumberdaya yang disediakan bagi organisasi pemeriksa, yang dapat berdampak negatif terhadap kemampuan organisasi pemeriksa tersebut dalam melaksanakan pemeriksaan, (c) gangguan organisasi, dimana dalam hal melakukan pemeriksaan,organisasi pemeriksa harus bebas dari hambatan independensi.Pemeriksa yang ditugasi oleh organisasi pemeriksa dapat dipandang bebas dari gangguan terhadap independensi secara organisasi, apabila melakukan pemeriksaan di luar entitas ia bekerja.

H1: Independensi memiliki pengaruh yang signifikan terhadap kualitas jasa audit pada KAP di Jakarta

\section{Kompetensi}

Menurut Siti Kurnia Rahayu dan Ely Suhayati (2009;2) menjelaskan kompetensi adalah auditor harus mempunyai kemampuan, ahli dan berpengalaman dalam memahami kriteria dan dalam menentukan jumlah bahan bukti yang dibutuhkan untuk dapat mendukung kesimpulan yang akan diambil. Menurut Lyle dan Spencer dalam Syaiful F Pribadi (2004:92) terdapat lima karakteristik dari kompetensi yaitu: (a) motif, adalah hal-hal yang berfikir oleh seseorang untuk berfikir dan memiliki keinginan secara konsisten yang akan dapat menimbulkan tindakan, (b)karakteristik, adalah karakteristik fisik dan responyang konsisten terhadap situasi atau informasi, (c) pengetahuan, adalah informasi yang dimiliki seseorang dalam bidang-bidang tertentu, (d) keterampilan, adalah kemampuan untuk melakukan tugas fisik atau mental.Menurut Siti Rahayu dan Ely Suhayati (2010:2)terdapat komponenkomponen yang harus dimiliki auditor yang kompeten yaitu: kemampuan, pengalaman, pelatihan dan pengetahuan.

H2: Kompetensi memiliki pengaruh yang signifikan terhadap kualitas jasa audit pada KAP di Jakarta

Pengalaman. Menurut Knoers dan Haditono (1999) Elisha (2010) mendefinisikan pengalaman sebagai:

"Pengalaman merupakan suatu proses pembelajaran dan penambahan perkembangan potensi bertingkah laku baik dari pendidikan formal maupun non formal atau bisa juga diartikan sebagai suatu proses yang membawa seseorang kepada suatu pola tingkah laku yang lebih tinggi."

Sedangkan Mulyadi (2002:24) mendefinisikan pengalaman auditor sebagai pengalaman auditor merupakan akumulasi gabungan dari semua yang diperoleh melalui interaksi. 
Dapat disimpulkan bahwa pengalaman auditor adalah orang - orang yang mempunyai keahlian di bidang audit yang senantiasa melakukan pembelajaran dari kejadian kejadian di masa lalu. Sebagian besar orang memiliki pemahaman bahwa semakin banyak jumlah jam terbang seorang auditor, tentunya dapat memberikan kualitas audit yang lebih baik bila dibandingkan dengan auditor yang baru saja memulai karirnya. Dengan kata lain, auditor yang berpengalaman diasumsikan dapat memberikan kualitas audit yang lebih baik dibandingkan dengan auditor yang belum berpengalaman (Elisha, 2010). Mulyadi (2002) menyatakan terdapat tiga faktor dalam pengalaman auditor yaitu pelatihan profesi, pendidikan dan lama kerja.

H3: Pengalaman memiliki pengaruh yang signifikan terhadap kualitas jasa audit pada KAP di Jakarta

Akuntabilitas Auditor. Akuntabilitas berasal dari Bahasa Inggris accountability yang berarti penanggungjawaban atau keadaan untuk dipertanggungjawabkan ataupun keadaan untuk diminta pertanggungjawaban. Libby dan Luft (1993), Cloyd (1997) dan Tan dan Alison (1999) dalam Diani dan Ria (2004) melihat bahwa terdapat tiga buah indikator yang dapat digunakan untuk mengukur akuntabilitas dari seorang individu. Indikator - indikator tersebut adalah: (a) seberapa besar motivasi mereka untuk menyelesaikan suatu pekerjaan, (b) seberapa besar usaha daya pikir yang diberikan untuk menyelesaikan sebuah pekerjaan, (c) seberapa yakin mereka bahwa pekerjaan mereka akan diawasi oleh atasan mereka. Elisha dan Icuk (2010:11) menyebutkan terdapat dua indikator akuntabilitas yaitu: (a) motivasi, Elisha dan Icuk (2010:11) berpendapat bahwa dengan adanya motivasi dalam bekerja, maka para auditor diharapkan untuk lebih memiliki intensitas, arah dan ketekunan sehingga tujuan organisasi akan lebih mudah untuk dicapai. (b) pengabdian profesi, Elisha dan Icuk (2010:11) berpendapat bahwa pengabdian profesi merupakan sebuah komitmen yang terbentuk dalam diri seorang profesional tanpa adanya paksaan dan secara sadar bertanggungjawab terhadap profesinya. Individu yang memiliki pengabdian profesi akan lebih menghargai pekerjaannya dibandingkan individu yang melakukan pekerjaan dengan unsur paksaan.

H4: Akuntabilitas auditor memiliki pengaruh yang signifikan terhadap kualitas jasa audit pada KAP di Jakarta

\section{METODE PENELITIAN}

Populasi yang digunakan dalam penelitian ini adalah para auditor yang bekerja di Kantor Akuntan Publik. Sampel yang diambil dari populasi di atas adalah para auditor yang bekerja pada Kantor Akuntan Publik di Jakarta. Responden dari penelitian ini adalah para auditor baik auditor junior, auditor senior, manajer maupun partner dalam suatu KAP. Teknik pengambilan sampel menggunakan metode simple random sampling. Pemilihan metode simple random samplingdengan mengambil secara acak untuk mengisi kuesioner dan menjadi sampel penelitian.Dengan metode simple random samplingdisebarkan 159 kuesioner kepada auditor yang bekerja dalam KAP di Jakarta.Dasar yang digunakan dalam menentukan seberapa banyak kuesioner yang disebarkan adalah jumlah auditor dan jumlah KAP yang ada di Jakarta. Sugiyono (2010:58) mendefinisikan operasional variabel sebagai segala sesuatu yang berbentuk apa saja yang ditetapkan oleh penelitiuntuk dipelajari sehingga diperoleh informasi tentang hal tersebut, kemudian ditarik kesimpulannya. Dalam penelitian ini variabel variabel yang digunakan adalah independensi auditor, kompetensi auditor, pengalaman auditor, akuntabilitas auditor dan kualitas jasa audit. 
Teknik pengumpulan data yang digunakan dalam penelitian ini adalah dengan data primer yaitu data dikumpulkan dengan cara menggunakan kuesioner yang langsung dikirim ke KAP tempat responden bekerja. Kuesioner ini nantinya akan disebarkan dan diisi oleh para auditor yang bekerja pada KAP di Jakarta. Untuk mendapatkan data yang relevan, maka penulis menggunakan beberapa teknik pengumpulan data antara lain: penelitian kepustakaan, dimana penelitian ini dilakukan dengan cara mengumpulkan dan membaca jurnal-jurnal maupun penelitian-penelitian yang telah dilakukan sebelumnya. Tujuan penelitian kepustakaan ini adalah agar penulis dapat membandingkan antara teori dan praktek yang telah dijalankan serta mengambil hal - hal yang dapat dijadikan dasar teoritis. Sedangkan penelitian lapangandilakukan dengan peninjauan langsung ke lapangan untuk mendapatkan data yang diperlukan. Pengumpulan data ini dilakukan dengan menggunakan kuesioner yang diajukan kepada auditor yang bekerja di KAP Jakarta.Kuesioner adalah alat riset atau survei yang terdiri atas serangkaian pertanyaan tertulis, bertujuan mendapatkan tanggapan dari kelompok orang terpilih melalui wawancara pribadi atau melalui daftar pertanyaan.

Kuesioner yang digunakan dalam penelitian ini berbentuk pertanyaan tertutup yaitu responden hanya bisa menjawab pertanyaan sesuai dengan jawaban yang telah disediakan oleh penulis. Setelah kuesioner dikumpulkan dari koresponden maka kuesioner akan diberikan nilai dengan menggunakan skala Likert. Menurut Sugiyono (2013:132), skala likert digunakan untuk mengukur sikap, pendapat dan persepsi seseorang atau sekelompok orang tentang fenomena sosial. Penilaian dengan skala Likert dapat disimpulkan sebagai berikut:

Tabel 1 Skala Likert

\begin{tabular}{|l|l|}
\hline Skala & Nilai \\
\hline Sangat setuju & 5 \\
\hline Setuju & 4 \\
\hline Netral & 3 \\
\hline Tidak setuju & 2 \\
\hline Sangat tidak setuju & 1 \\
\hline
\end{tabular}

Uji validitas Azwar (2000) mendefinisikan validitas dengan sejauh mana ketepatan dan kecermatan suatu alat ukur dalam melakukan fungsinya. Validitas adalah suatu derajat ketepatan instrumen (alat ukur). Kegunaan dari validitas adalah untuk mengetahui sejauh mana ketepatan dan kecermatan suatu instrumen pengukuran dalam melakukan fungsi ukurnya yaitu agar data yang diperoleh bisa sesuai dengan tujuan diadakannya pengukuran. Pengukuran validitas dilakukan dengan menggunakan analisis faktor dengan cara mengkorelasikan jumlah skor item kuesioner dengan skor total. Kriteria yang digunakan dalam pengujian validitas adalah dengan membandingkan $\mathrm{R}_{\text {hitung }}$ dengan $\mathrm{R}_{\text {tabel. }}$. AngkaR $\mathrm{R}_{\text {hitung }}$ dapat dilihat pada kolom corrected item total correlation. Apabila nilai $R_{\text {hitung }}>R_{\text {tabel }}$ maka butir pernyataan tersebut bisa dinyatakan valid. Selanjutnya uji reabilitas adalah sebuah pengujian yang dilakukan untuk mengetahui apakah data yang didapat sudah kompeten atau sudah sesuai dengan keadaan yang sebenarnya.

Pengujian Asumsi Klasik

Pengujian asumsi klasik merupakan pengujian asumsi - asumsi statistik yang harus dipenuhi pada analisis regresi linear berganda. Terdapat enam uji asumsi klasik yang dapat dilakukan terhadap suatu model regresi, yaitu: (1) uji normalitas, (2) uji 
homogenitas, (3) uji Linieritas, (4) uji Multikolinieritas, (5) uji heteroskedasitisitas dan (6) uji autokorelasi. Asumsi klasik yang akan diuji meliputi multikolnieritas, heteroskedasitisitas dan normalitas.

Pertama. Multikolinieritas. Uji asumsi klasik Multikolinieritas digunakan untik mengetahui apakah terjadi hubungan linear yang sempurna atau mendekati sempurna antara variabel independen dalam sebuah model regresi. Model regresi yang baik adalah model regresi yang tidak memiliki masalah multikolinearitas. Cara untuk melihat apakah terjadi masalah multikolinearitas atau tidak adalah dengan melihat Variance Inflation Factors (VIF) dalam model regresi. Apabila nilai VIF<10 dan nilai tolerance $>0,1$, maka dapat disimpulkan bahwa tidak terjadi masalah multikolienearitas.

Kedua. Heteroskedastisitas. Uji Heteroskedastisitas bertujuan untuk menguji apakah dalam model regresi terjadi ketidaksamaan varians dari residual satu pengamatan ke pengamatan yang lain. Cara yang dapat digunakan untuk melakukan uji heteroskedasitisitas adalah dengan menggunakan uji Glejser dimana apabila nilai signifikasi > 0,05, maka model regresi bebas dari masalah heteroskedastisitas.

Ketiga. Normalitas. Pengujian asumsi normalitas untuk menguji data variabel bebas (X) dan variabel terikat (Y) pada persamaan regresi yang dihasilkan, apakah berdistribusi normal atau berdistribusi tidak normal. Jika distribusi data normal, maka analisis data dan pengujian hipotesis digunakan statistik parametrik. Cara yang digunakan untuk melakukan uji ini adalah dengan menggunakan uji Kolmogorov-Smirnov.Jika nilai signifikansi >0.05, maka data yang digunakan telah terdistribusi secara normal.

\section{Teknik Pengujian Hipotesis}

Pengujian hipotesis dilakukan untuk mendapatkan gambaran mengenai pengaruh dan perbedaan antara variabel independen dan variabel dependen. Penelitian ini menggunakan model regresi linear berganda dengan persamaan:

$\mathrm{Y}=\mathrm{a}+\mathrm{b}_{1} \mathrm{X}_{1}+\mathrm{b}_{2} \mathrm{X}_{2}+\mathrm{b}_{3} \mathrm{X}_{3}+\mathrm{b}_{4} \mathrm{X}_{4}$ Dimana:

$\mathrm{Y}=$ Kualitas

audit $\mathrm{a}=$

Konstanta

$\mathrm{X}_{1}=$ Variabel independensi

$\mathrm{X}_{2}=$ Variabel kompetensi

$\mathrm{X}_{3}=$ Variabel pengalaman

$\mathrm{X}_{4}=$ Variabel akuntabilitas auditor

$\mathrm{B}_{1}=$ Koefisien regresi indepensi

$\mathrm{B}_{2}=$ koefisien regresi kompetensi

$\mathrm{B}_{3}=$ koefisien regresi pengalaman

$\mathrm{B}_{4}=$ koefisien regresi akuntabilitas auditor

Statistik parametik yang digunakan untuk pengujian dalam penelitian ini adalah sebagai berikut: (1) Uji t, digunakan untuk melihat apakah dalam model regresi variabel independen secara parsial berpengaruh signifikan terhadap variabel dependen. Nilai signifikansi harus dibandingkan dengan tingkat alpha( $\alpha)$ yang telah ditentukan, yaitu 0,05. Jika sig $<\alpha$ maka variabel dependen berpengaruh signifikan terhadap variabel dependen. (2) Uji F (ANOVA), digunakan untuk mengetahui apakah variabel dependen secara simultan berpengaruh signifikan terhadap variabel independennya. Kritera pengujiannya adalah apabila nilai signifikasi $>0,05$, maka hipotesis diterima, begitu pula sebaliknya. (3) Uji $\mathrm{R}^{2}$ (koefisien determinasi), pengujian ini dilakukan untuk mengetahui persentase sumbangan pengaruh variabel indpenden secara simultan terhadap variabel independen. Apabila nilai $\mathrm{R}^{2}$ mendekati satu maka variabel - variabel independen 
memberikan hampir seluruh informasi yang dibutuhkan untuk memprediksi variabel dependen.

\section{HASIL DAN PEMBAHASAN}

Data yang digunakan dalam penelitian adalah data penelitian primer. Data penelitian diperoleh dengan menyebarkan kuesioner kepada responden yang dituju yaitu kepada auditor yang bekerja di Kantor Akuntan Publik di Jakarta, baik yang berprofesi sebagai junior auditor, senior auditor,manager,maupunpartner. Dalam melaksanakan tugasnya responden bertanggungjawab untuk menjalankan proses audit, yang melakukan pemeriksaan terhadap laporan keuangan. Kuesioner yang disebarkan pada Kantor Akuntan Publik (KAP) di Jakarta dalam penelitian ini sebanyak 159 kuesioner. Dari total tersebut yang telah dikembalikan dan diisi adalah sebanyak 128 buah atau 80,50\%.

Rincian dari sampel dan tingkat pengemballian kuesioner disajikan sebagai berikut

Tabel 2 Jumlah Sampel dan Tingkat Pengembalian Kuesioner

\begin{tabular}{|c|c|c|c|c|c|c|c|}
\hline \multirow[b]{3}{*}{ KAP } & \multirow[b]{3}{*}{ Disebarkan } & \multicolumn{6}{|c|}{ Jumlah Kuesioner } \\
\hline & & \multicolumn{2}{|c|}{ Kembali } & \multicolumn{2}{|c|}{ Gugur } & \multicolumn{2}{|c|}{ Terpakai } \\
\hline & & Jumlah & $\%$ & Jumlah & $\%$ & Jumlah & $\%$ \\
\hline $\begin{array}{l}\text { KAP Drs. Tjhin } \\
\text { Tjiap }\end{array}$ & & & & & & & \\
\hline Lung.MM.BAP & 15 & 15 & 9,43 & 0 & 0 & 15 & 11,72 \\
\hline $\begin{array}{l}\text { KAP Kosasih, } \\
\text { Nurdiyaman, } \\
\text { Tjahjo \& Rekan } \\
\text { (Crowe } \\
\text { Horwath) }\end{array}$ & 15 & 15 & 9,43 & 0 & 0 & 15 & 11,72 \\
\hline $\begin{array}{l}\text { KAP Arman } \\
\text { Dhani \& Rekan }\end{array}$ & 5 & 5 & 3,15 & 0 & 0 & 5 & 3.9 \\
\hline $\begin{array}{l}\text { KAP Handoko \& } \\
\text { Suparmun }\end{array}$ & 8 & 6 & 3,77 & 2 & 0 & 6 & 4.69 \\
\hline $\begin{array}{lr}\text { KAP } & \text { Johan } \\
\text { Malonda } & \\
\text { Mustika } & \text { \& } \\
\text { Rekan } & \\
\end{array}$ & 20 & 10 & 6,29 & 10 & 0 & 10 & 7,81 \\
\hline $\begin{array}{l}\text { KAP Leonard, } \\
\text { Mulia dan } \\
\text { Richard }\end{array}$ & 10 & 10 & 6,29 & 0 & 0 & 10 & 7,81 \\
\hline $\begin{array}{l}\text { KAP Michelle } \\
\text { Kristian }\end{array}$ & 20 & 5 & 3,15 & 15 & 0 & 5 & 3,90 \\
\hline $\begin{array}{lr}\text { KAP } & \text { Ecovis } \\
\text { Idris } & \& \\
\text { Sudiharto } & \\
\end{array}$ & 10 & 6 & 3,77 & 4 & 0 & 6 & 4,69 \\
\hline
\end{tabular}




\begin{tabular}{|c|c|c|c|c|c|c|c|}
\hline $\begin{array}{l}\text { KAP Herman } \\
\text { Dody } \\
\text { Tanumihardja \& } \\
\text { Rekan }\end{array}$ & 21 & 21 & 13,21 & 0 & 0 & 21 & 16,41 \\
\hline $\begin{array}{l}\text { KAP Mulyamin } \\
\text { Sensi Suryanto }\end{array}$ & 20 & 20 & 12,58 & 0 & 0 & 20 & 15,63 \\
\hline \& Lianny & & & & & & & \\
\hline $\begin{array}{l}\text { KAP Moch. } \\
\text { Zainuddin \& } \\
\text { Sukmadi }\end{array}$ & 15 & 15 & 9,43 & 0 & 0 & 15 & 11,72 \\
\hline Total & 159 & 128 & 80,50 & 0 & 0 & 128 & 100 \\
\hline
\end{tabular}

Sumber: Hasil Penelitian, 2014 (Diolah)

Statistik deskriptif responden digunakan untuk memberikan informasi yang dapat menggambarkan responden agar dapat diketahui secara keseluruhan berdasarkan karakteristiknya. Dalam statistik deskriptif ini yang peneliti lakukan adalah mengelompokkan data yang telah diperoleh serta menentukan nilai dan fungsi statistik. Karakteristik dalam penelitian ini dapat digolongkan menjadi: pendidikan, jabatan dan masa bekerja sebagai auditor. Karakteristik dari responden auditor dirangkum kembali dari kuesioner yang kembali dan memenuhi kriteria untuk dijadikan sampel penelitian.Berikut ini adalah karakterikstik responden yang dirangkum dari kuesioner, disajikan dalam Tabel 3.

Tabel 3 Karakteristik Responden

\begin{tabular}{|c|c|c|c|}
\hline No. & Keterangan & Jumlah & $\%$ \\
\hline \multirow[t]{2}{*}{1} & \begin{tabular}{ll}
\multicolumn{2}{l}{ Pendidikan : } \\
- & SMA \\
- & S1 $-\mathrm{S} 2$ \\
- & S3 \\
- & Lainnya
\end{tabular} & $\begin{array}{l}4 \\
100 \\
18 \\
3 \\
3\end{array}$ & $\begin{array}{l}3,1 \\
78,1 \\
14,1 \\
2,3 \\
2,3\end{array}$ \\
\hline & & 128 & 100 \\
\hline \multirow[t]{2}{*}{2} & $\begin{array}{l}\text { Jabatan : } \\
\text { - Auditor Junior } \\
\text { - Auditor Senior } \\
\text { - Manager } \\
\text { - Partner }\end{array}$ & $\begin{array}{l}68 \\
45 \\
7 \\
8\end{array}$ & $\begin{array}{l}53,1 \\
35,2 \\
5,5 \\
6,3\end{array}$ \\
\hline & & 128 & 100 \\
\hline \multirow[t]{2}{*}{3} & $\begin{array}{l}\text { Masa Bekerja : } \\
\cdot \quad<5 \text { Tahun } \\
\cdot \quad 5-10 \text { Tahun } \\
\cdot \quad 10-15 \text { Tahun } \\
\cdot \quad>15 \text { Tahun }\end{array}$ & $\begin{array}{l}81 \\
29 \\
10 \\
8\end{array}$ & $\begin{array}{l}63,3 \\
22,7 \\
7,8 \\
6,3\end{array}$ \\
\hline & & 128 & 100 \\
\hline
\end{tabular}

Sumber: Hasil penelitian, 2014 ( Diolah) 
Dari hasil Uji Validitas menunjukan bahwa semua pertanyaan yang ada pada kuesioner mempunyai nilai signifikansi lebih kecil dari 0,005 $(<0,005)$, dan sesuai dengan dasar analisi yang digunakan, hal ini berarti bahwa seluruh pertanyaan dapat digunakan dalam penelitian. Hasil realibilitas menunjukan besarnya nilai Cronbach Alpha pada seluruh variabel lebih besar dari 0,60 dan sesuai dengan dasar analisis yang digunakan, hal ini menunjukkan bahwa seluruh variabel yang digunakan dalam penelitian seluruhnya reliabel.

\section{Uji Asumsi Klasik}

Sebelum data dianalisis dengan menggunakan analisis regresi linear berganda, pengujian asumsi klasik perlu dilakukan terlebih dahulu. Dengan terpenuhinya uji asumsi klasik, maka suatu variabel dapat dinyatakan layak digunakan untuk memprediksi variabel lainnya. Uji asumsi klasik yang digunakan dalam penelitian ini adalah uji multikolinearitas, uji heteroskedastisitas, dan uji normalitas.

Pertama. Uji Multikolinearitas.Uji Multikolinearitas bertujuan untuk mengetahui apakah terjadi hubungan linear yang sempurna atau mendekati sempurna antar variabel independen dalam model regresi.Model regresi yang baik adalah model yang tidak memiliki masalah multikolinearitas.Cara mendeteksi multikolinearitas adalah dengan melihat Variance Inflation Factors (VIF) pada model regresi.Apabila nilai VIF < 10 dan nilai tolerance $>0,1$, maka tidak terjadi multikolinearitas.

Tabel 4 Uji Multikolinearitas

Coefficients $^{\text {a }}$

\begin{tabular}{|c|c|c|c|c|c|c|c|c|}
\hline \multirow{2}{*}{\multicolumn{2}{|c|}{ Model }} & \multicolumn{2}{|c|}{$\begin{array}{c}\text { Unstandardized } \\
\text { Coefficients }\end{array}$} & \multirow{2}{*}{$\begin{array}{c}\text { Standardized } \\
\text { Coefficients } \\
\text { Beta }\end{array}$} & \multirow[b]{2}{*}{$\mathrm{t}$} & \multirow[b]{2}{*}{ Sig. } & \multicolumn{2}{|c|}{$\begin{array}{c}\text { Collinearity } \\
\text { Statistics }\end{array}$} \\
\hline & & B & Std. Error & & & & Tolerance & VIF \\
\hline \multirow[t]{5}{*}{1} & (Constant) & 7.899 & 2.824 & & 2.797 & .006 & & \\
\hline & Independensi & .443 & .086 & .366 & 5.179 & .000 & .754 & 1.327 \\
\hline & Pengalaman & .480 & .149 & .221 & 3.217 & .002 & .796 & 1.257 \\
\hline & Akuntabilitas & .319 & .125 & .199 & 2.559 & .012 & .618 & 1.618 \\
\hline & Auditor & .575 & .172 & .230 & 3.348 & .001 & .794 & 1.260 \\
\hline
\end{tabular}

a. Dependent Variable: Kualitas Jasa Audit

Sumber : Hasil Penelitian,2014 (SPSS)

Berdasarkan tabel 4, dapat dilihat bahwa nilai VIF untuk variabel independensi adalah 1,327 , kompetensi sebesar 1,257, pengalaman sebesar 1,618, dan akuntabilitas auditor sebesar 1,260, maka dapat disimpulkan bahwa data penelitian bebas dari masalah miultikolinearitas. Dengan demikian model regresi ini telah memenuhi asumsi multikolinearitas.

Kedua. Uji Heteroskedastisitas.Uji Heteroskedastisitas dilakukan untuk mengetahui apakah terjadi ketidaksamaan varian dari residual untuk semua pengamatan pada model regresi. Model regresi yang baik adalah model yang tidak memiliki masalah heteroskedastisitas. Cara yang digunakan untuk melakukan uji heteroskedastisitas 
adalah dengan menggunakan uji Glejser. Jika nilai signifikansi $>0,05$, maka model regresi bebas dari masalah heteroskedastisitas.

Sumber : Hasil Penelitian, 2014 (SPSS)

Tabel 5 Uji Heteroskedastisitas dengan Menggunakan Uji Glejser

Coefficients $^{\text {a }}$

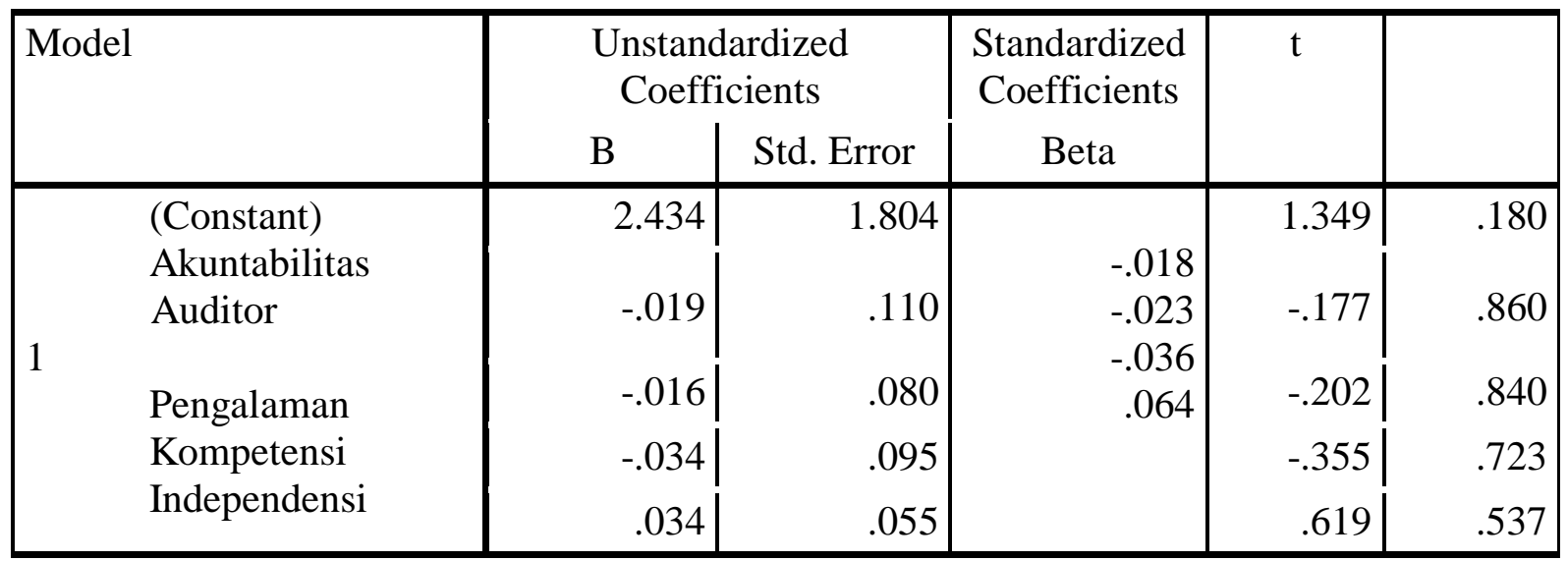

a. Dependent Variable: ABSRES

Pada Tabel 5 terlihat bahwa nilai signifikansi untuk variabel independensi menunjukkan nilai signifikansi sebesar 0,860, variabel kompetensi menunjukkan nilai signifikansi sebesar 0,840, variabel pengalaman menunjukkan nilai signifikansi 0,723 , dan variabel akuntabilitas auditor menunjukkan nilai signifikansi 0,537, dimana hasil ini lebih besar dari 0,05. Hal ini menunjukkan bahwa tidak terjadi heteroskedastisitas pada data penelitian. Dapat disimpulkan bahwa model regresi ini telah memenuhi asumsi heteroskedastisitas.

Ketiga. Uji Normalitas. Uji Normalitas digunakan untuk mengetahui apakah populasi data berdistribusi normal atau tidak. Cara yang digunakan untuk melakukan uji normalitas adalah dengan menggunakan uji Kolmogorov-Smirnov. Jika nilai signifikansi $>0,05$, maka data yang digunakan telah terdistribusi secara normal.

Tabel 6 Uji Normalitas dengan Menggunakan Uji Kolmogorov-Smirnov One-Sample Kolmogorov-Smirnov Test

\begin{tabular}{|ll|r|}
\hline & & Unstandardized Residual \\
& & 128 \\
Normal Parameters ${ }^{\mathrm{a}, \mathrm{b}}$ & Mean & $0 \mathrm{E}-7$ \\
& Std. Deviation & 2.75523888 \\
& Absolute & .068 \\
& Positive & .068 \\
Most Extreme Differences & Negative & -.053 \\
& & .771 \\
Kolmogorov-Smirnov Z & & .593 \\
Asymp. Sig. (2-tailed) & & \\
\hline
\end{tabular}

a. Test distribution is Normal.

b. Calculated from data.

Sumber : Hasil Penelitian, 2014 (SPSS) 
Berdasarkan pada Tabel 6, dapat dilihat bahwa nilai signifikansi yang diperoleh adalah sebesar 0,593, hasil ini lebih besar dari 0,05. Hal ini berarti bahwa data penelitian telah terdistribusi secara normal. Dengan demikian dapat disimpulkan bahwa model regresi ini telah memenuhi asumsi normalitas.

\section{Hasil Pengujian Regresi}

Koefisien Regresi digunakan untuk mengetahui apakah terdapat pengaruh antara variabel independen terhadap variabel dependen dan seberapa besar pengaruh besar tersebut.

Tabel 7 Hasil Analisis Regresi Berganda

Coefficients $^{\mathrm{a}}$

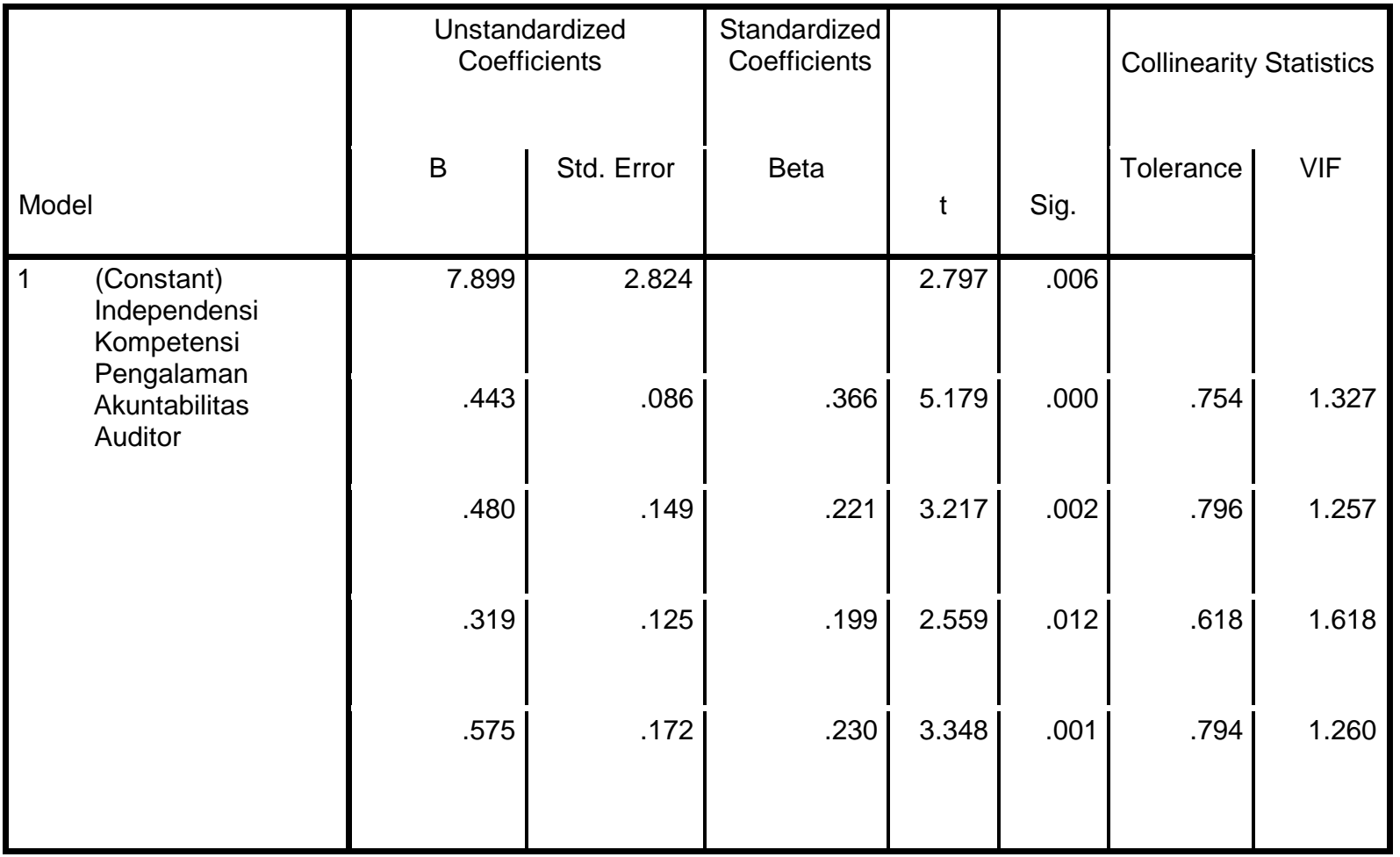

a. Dependent Variable: Kualitas Jasa Audit

Sumber : Hasil Penelitian, 2014 ( SPSS)

Hasil dari pengujian hipotesis dengan analisis regresi linear berganda dapat dibuat menjadi model persamaan regresi dan dijelaskan sebagai berikut: $Y=a+b_{1} X_{1}+b_{2} X_{2}+$ $\mathrm{b}_{3} \mathrm{X}_{3}+\mathrm{b}_{4} \mathrm{X}_{4}$

$$
\mathrm{Y}=7,899+0,443 \mathrm{X}_{1}+0,480 \mathrm{X}_{2}+0,319 \mathrm{X}_{3}+0,575 \mathrm{X}_{4}
$$

Keterangan:

$$
\begin{array}{ll}
\mathrm{Y} & =\text { Kualitas jasa audit } \\
\mathrm{a} & =\text { Nilai } \text { intercept } \text { atau konstanta } \\
\mathrm{b}_{1}, \mathrm{~b}_{2}, \mathrm{~b}_{3}, \mathrm{~b}_{4} & =\text { Slope Coefficient } \\
\mathrm{X}_{1} & =\text { Independensi } \\
\mathrm{X}_{2} & =\text { Kompetensi } \\
\mathrm{X}_{3} & =\text { Pengalaman } \\
\mathrm{X}_{4} & =\text { Akuntabilitas auditor }
\end{array}
$$

Dari persamaan tersebut, dapat dilihat bahwa variabel independensi, kompetensi, pengalaman, dan akuntabilitas auditor berpengaruh terhadap kualitas jasa audit. Hasil pengujian menunjukkan bahwa konstanta adalah sebesar 7,899, artinya apabila variabel independensi $\left(\mathrm{X}_{1}\right)$, kompetensi $\left(\mathrm{X}_{2}\right)$, pengalaman $\left(\mathrm{X}_{3}\right)$, dan akuntabilitas auditor $\left(\mathrm{X}_{4}\right)$ 
besarnya $=0$, maka kualitas auditnya adalah 7,899. Persamaan regresi menunjukkan koefisien regresi variabel independensi $\left(\mathrm{X}_{1}\right)$ sebesar 0,443 , artinya jika variabel independensi mengalami kenaikan sebesar 1 satuan, maka kualitas audit akan mengalami kenaikan sebesar 0,443 satuan dengan asumsi bahwa variabel independen lainnya tetap atau konstan. Persamaan regresi menunjukkan koefisien regresi variabel kompetensi $\left(\mathrm{X}_{2}\right)$ sebesar 0,480 , artinya jika variabel kompetensi mengalami kenaikan sebesar 1 satuan, maka kualitas audit akan mengalami kenaikan sebesar 0,480 satuan dengan asumsi bahwa variabel independen lainnya tetap atau konstan. Persamaan regresi menunjukkan koefisien regresi variabel pengalaman $\left(\mathrm{X}_{3}\right)$ sebesar 0,319 , artinya jika variabel pengalaman mengalami kenaikan sebesar 1 satuan, maka kualitas audit akan mengalami kenaikan sebesar 0,319 satuan dengan asumsi bahwa variabel independen lainnya tetap atau konstan. Persamaan regresi menunjukkan koefisien regresi variabel akuntabilitas auditor $\left(\mathrm{X}_{4}\right)$ sebesar 0,575 , artinya jika variabel akuntabilitas auditor mengalami kenaikan sebesar 1 satuan, maka kualitas audit akan mengalami kenaikan sebesar 0,575 satuan dengan asumsi bahwa variabel independen lainnya tetap atau konstan.

Uji F. Pengujian dengan ANOVA berdasarkan nilai signifikansi F sehingga disebut Uji F. Uji $\mathrm{F}$ ini dimaksudkan untuk mengetahui apakah terdapat pengaruh dari variabel independen secara simultan terhadap variabel dependen.

Tabel 8 Hasil Uji F dengan Variabel Dependen Kualitas Jasa Audit ANOVA ${ }^{a}$

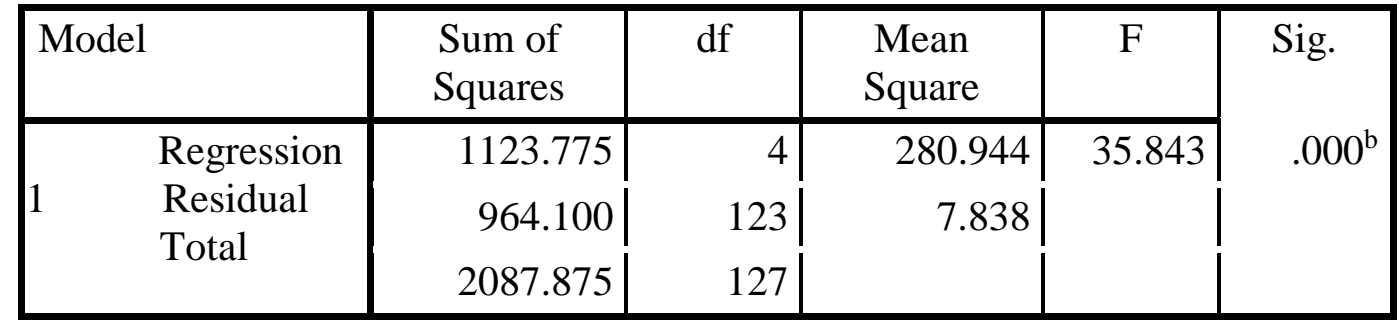

a. Dependent Variable: Kualitas Jasa Audit

b. Predictors: (Constant), Akuntabilitas Auditor, Independensi, Kompetensi, Pengalaman

Sumber: Hasil Penelitian, 2014 (SPSS)

Keempat variabel independen tersebut juga diuji bersama-sama dan diperoleh nilai signifikansi 0.000 (lebih kecil dari $\alpha=0.05$ ). Hal ini menunjukkan secara bersamaan (simultan) independensi, kompetensi, pengalaman, dan akuntabilitas auditor menunjukkan pengaruh yang signifikan dalam menentukan kualitas jasa audit. Dengan demikian dapat disimpulkan hipotesis kelima yang menyatakan bahwa terdapat pengaruh yang signifikan antara independensi, kompetensi, pengalaman, dan akuntabilitas auditor terhadap kualitas jasa audit yang terbentuk dalam penelitian ini dapat digunakan.

Uji T. Untuk menguji hipotesis digunakan uji regresi parsial. Uji parsial ini dimaksudkan untuk mengetahui ada tidaknya pengaruh dari masing-masing variable independen terhadap variabel dependen. Untuk mengetahui ada atau tidaknya pengaruh suatu variabel independen terhadap variabel dependen dugunakan ukuran signifikansi. Nilai sig tersebut harus dibandingkan dengan tingkat alpha $(\alpha)$ yang telah ditentukan, yaitu 0,05. Jika sig $<\alpha$ maka variabel independen berpengaruh signifikan terhadap variabel dependen. 
Tabel 9 Hasil Uji Hipotesis t-test dengan Variabel Dependen Kualitas Jasa Audit

Coefficients ${ }^{\text {a }}$

\begin{tabular}{|c|c|c|c|c|c|c|c|}
\hline \multirow[t]{2}{*}{ Model } & \multicolumn{2}{|c|}{$\begin{array}{l}\text { Unstandardized } \\
\text { Coefficients }\end{array}$} & \multirow{2}{*}{$\begin{array}{c}\text { Standardized } \\
\text { Coefficients } \\
\text { Beta }\end{array}$} & \multirow[t]{2}{*}{$\mathrm{t}$} & \multirow[t]{2}{*}{ Sig. } & \multicolumn{2}{|c|}{$\begin{array}{l}\text { Collinearity } \\
\text { Statistics }\end{array}$} \\
\hline & B & Std. Error & & & & Tolerance & VIF \\
\hline (Constant) & 7.899 & 2.824 & & 2.797 & .006 & & \\
\hline Independensi & .443 & .086 & .366 & 5.179 & .000 & .754 & 1.327 \\
\hline Kompetensi & .480 & .149 & .221 & 3.217 & .002 & .796 & 1.257 \\
\hline Pengalaman & .319 & .125 & .199 & 2.559 & .012 & .618 & 1.618 \\
\hline $\begin{array}{l}\text { Akuntabilitas } \\
\text { Auditor }\end{array}$ & .575 & .172 & .230 & 3.348 & .001 & .794 & 1.260 \\
\hline
\end{tabular}

a. Dependent Variable: Kualitas Jasa Audit

Sumber : Hasil Penelitian, 2014 (SPSS)

Berdasarkan hasil uji terdapat nilai signifikansi untuk variabel independensi sebesar 0,000 (lebih kecil dari $\alpha=0,05$ ), maka dapat disimpulkan independensi auditor berpengaruh signifikan terhadap kualitas audit. Untuk variabel kedua yaitu kompetensi, terdapat nilai signifikansi sebesar 0,002 (lebih kecil dari $\alpha=0,05$ ), maka dapat disimpulkan kompetensi berpengaruh positif terhadap kualitas jasa audit. Variabel ketiga pengalaman memiliki nilai signifikansi 0,012 (lebih kecil dari $\alpha=0,05$ ), maka dapat disimpulkan pengalaman memiliki pengaruh signifikan positif terhadap kualitas audit. Variabel keempat akuntabilitas auditor memiliki nilai signifikansi 0,001 (lebih kecil dari $\alpha=0,05$ ), maka dapat disimpulkan akuntabilitas auditor memiliki pengaruh signifikan positif terhadap kualitas audit.

\section{KESIMPULAN DAN SARAN}

Hasil dari Uji Koefisien berganda $\left(\mathrm{R}^{2}\right)$ diperoleh hasil bahwa independensi, kompetensi, pengalaman, dan akuntabilitas auditor secara bersama-sama dapat menjelaskan variabel kualitas jasa audit sebesar 52,3\%. Sedangkan 47,7\% dijelaskan oleh variabel - variabel lain seperti etika profesi auditor, fee audit, due professional care, dan faktor - faktor lainnya.

Dari hasil penelitian yang telah dilakukan, independensi auditor mempengaruhi Kualitas Jasa Audit sebesar 57,7\%, kompetensi auditor mempengaruhi Kualitas Jasa Audit sebesar 46,6\%, pengalaman auditor mempengaruhi Kualitas Jasa Audit sebesar 56,6\%, akuntabilitas auditor mempengaruhui Kualitas Jasa Audit sebesar 48,4\%.

Hipotesis pertama yang menyatakan bahwa independensi auditor berpengaruh signifikan positif dapat dibuktikan melalui penelitian ini. Hasil penelitian ini sesuai dengan penelitian sebelumnya yang dilakukan oleh Elisha Muliani Singgih dan Icuk Rangga Bawono (2010).

Hipotesis kedua yang menyatakan bahwa kompetensi auditor berpengaruh signifikan positif dapat dibuktikan melalui penelitian ini. Hasil penelitian ini sesuai dengan penelitian terdahulu yang dilakukan oleh Amalia Dewi Rosalina (2014).

Hipotesis ketiga yang menyatakan bahwa pengalaman auditor berpengaruh signifikan positif dapat dibuktikan melalui penelitian ini dan mendukung penelitian sebelumnya yang telah dilakukan oleh A Basit Fauzi Nugraha (2012). 
Hipotesis keempat yang menyatakan bahwa akuntabilitas auditor berpengaruh signifikan positif dapat dibuktikan melalui penelitian ini dan mendukung penelitian terdahulu yang dilakukan oleh Elisha Muliani Singgih dan Icuk Rangga Bawono (2010).

\section{REFERENSI}

Agoes, Sukrisno. 2012. Auditing: Petunjuk Praktik Pemeriksaan Akuntan oleh Akuntan Publik. Jakarta. Salemba Empat.

Arens, A. A., R. J. Elder, dan M. S. Beasley. 2012. Auditing and Assurance Service An Integrated Approach, 14th Edition. England: Pearson Education Limited

Azwar, Saifuddin. 2000. Reliabilitas dan Validitas. Yogyakarta. Pustaka Belajar

Futri, Septiani Putu dan Gede Juliarsa. 2014. Pengaruh Independensi, Profesionalisme, Tingkat Pendidikan, Etika Profesi, Pengalaman, dan Kepuasan Kerja Auditor pada

Kualitas Audit Kantor Akuntan Publik di Bali. E-Journal Akuntansi Universitas Udayana. p.444 - 461.Bali

Ghozali Imam, Prof, Dr, H., M. Com, Ak. 2012. Aplikasi Analisis Multivariate dengan Program IBM SPSS 20. Semarang. Badan Penerbit Universitas Diponegoro.

Institut Akuntan Publik Indonesia. 2011. Standar Profesional Akuntan Publik. Jakarta. Salemba Empat.

Mulyadi. 2002. Auditing Edisi 6 Buku Dua. Jakarta. Salemba Empat.

Nugraha, A Basit Fauzi. 2012. Pengaruh Pengalaman, Due Proffesional Care, dan Independensi Auditor terhadap Kualitas Audit. Jurnal Universitas Komputer Indonesia.Bandung

Rosalina, Amalia Dewi. 2014. Pengaruh Kompetensi dan Independensi Auditor terhadap Kualitas Audit (Pada Kantor Akuntan Publik di Wilayah Bandung). Artikel Universitas Widyatama. Bandung

Singgih, Elisha Muliani dan Icuk Rangga Bawono.2010. Pengaruh Independensi, Pengalaman, Due Professional Care, dan Akuntabilitas terhadap Kualitas Audit. Simposum Nasional Akuntansi XIII. Purwokerto.

Sugiyono Prof. Dr.,2010. Metode Penelitian Pendidikan Pendekatan Kuantitatif, Kulaitatif dan $R \& D$, Bandung. Cv. Alfa Beta.

Syaiful F. Prihadi, 2004. Assesment Centre, Gramedia Pustaka Utama, Jakarta. 